Journal of Operations Management, Volume 29, 2011, Issue 7-8, Pages 707-720

\title{
Product safety and security in the global supply chain: Issues, challenges and research opportunities
}

Ann Marucheck, Kenan-Flagler Business School, University of North Carolina, marucheck@unc.edu

Noel Greis, Kenan-Flagler Business School, University of North Carolina, greis@unc.edu

Carlos Mena, Cranfield School of Management, Cranfield University, carlos.mena@cranfield.ac.uk

Linning Cai, Department of Industrial Engineering, Tsinghua University, cailn@tsinghua.edu.cn

\begin{abstract}
A number of high profile product safety events and recalls have heightened public attention to the safety and security of the products that people consume and use. While product safety isn't a new topic, the effect of the global supply chain in creating or exacerbating safety risks and vulnerabilities is both timely and relevant. In this essay we focus on how the field of operations management can provide fresh perspectives and insights in addressing the challenges of product safety and security in the global supply chain. We first examine the product safety issues and challenges that arise in five industries that are increasingly globalizing their supply chains: food, pharmaceuticals, medical devices, consumer products and automobiles. We describe four areas where operations management theory and methodologies can provide fresh insights and innovative solutions in addressing these problems; regulation and standards, product lifecycle management, traceability and recall management, and supplier relationships.
\end{abstract}

\section{Introduction}

A series of high profile product recalls in recent years has shaken public confidence in the ability of manufacturers and governments to assure the safety of food and other products used by consumers (Gallup, 2008). In the past, product failures were often attributed to local or functional errors in product design, the manufacturing process, or inadequate labeling with limited impact. Today a single product safety problem can have significant repercussions on a global scale (Marucheck, 1987). For example, recent recalls by Toyota in 2009 and 2010 not only incurred huge litigation fees, but also resulted in estimated losses in the billions of dollars due to lost sales, reduced manufacturing output, and enhanced incentive campaigns. The effects of this recall were felt not only in the U.S., but also around the world in the many countries where Toyota has a market presence (Sanchanta and Takahasi, 2010). For a wide range of products from food and drugs to consumer products, medical devices and 
automobiles, product safety problems are magnified in terms of scope and scale within today's global economy. Globalization of most industries has sparked heightened awareness of the various risks and vulnerabilities that products are exposed to as they move along the supply chain continuum from design and sourcing to manufacture, transportation, distribution and final sale to the consumer. Supply networks are long and complex. Many entities including outsourcers and subcontractors located in emerging economies such as China handle the product as it moves across geographical and national borders, thereby creating many physical and temporal threats that pose a risk to product safety and security. Lee et al. (2008) address product recalls from the perspective of the supply chain, particularly in China, highlighting the challenges that companies face in a highly globalized business environment, including the importance of relationships and the impact of cultural misunderstandings.

The topic of product safety and security is an emerging area within the domain of supply chain risk management, and it has received increased academic attention during the last decade (Lee and Whang, 2005; Pyke and Tang, 2010; Tang, 2008; Wein and Liu, 2005). In characterizing supply chain risk as a disruption or negative outcome triggered by unpredictable and/or uncertain events, Narasimhan and Talluri (2009) used a food safety accident to illustrate how risk may be manifested throughout a global supply chain. Although the number of papers addressing risk management within a supply chain continues to grow, there is currently no universally accepted classification of the different types of risks experienced within supply chain although Chopra and Sodhi (2004), Hendricks and Singhal (2003, 2005), Tang (2006) and Wagner and Bode (2006), among others, offer various classifications and typologies. Most of these risk categories address events that may precipitate negative consequences with respect to the flow of product through the supply chain. However, to the best of our knowledge, none of these classifications address the effects of undesirable events on the integrity of the product. We are concerned with the risk to a product - particularly with respect to its composition, ability to perform its intended use, and adequacy of its packaging and labelling - when the outcome of some deviation could result in the compromised health or safety of users or of other people, property or equipment who may be in proximity of its use.

Product safety refers to the reduction in the probability that use of a product will result in illness, injury, death or negative consequences to people, property or equipment. We broadly define use to mean that the product may be consumed, physically implanted into the body, or placed into physical use. While some safety issues can be traced back to design flaws, manufacturing or processing defects, software problems, and packaging errors (or a combination of these), a supply chain perspective highlights the safety problems that can arise at transfers in the system from improper storage, handling and distribution of the product (Thirumalai and Sinha, 2011). For example, the source of a particularly virulent 
Escherichia coli contamination of hamburger meat in 2007, which resulted in serious illnesses for several consumers, was never identified (Moss, 2009). A follow-up investigation revealed that the contamination could have arisen at any step of the supply chain, starting from the slaughter house operations of several different suppliers, one located in Uruguay, to final grinding of the meat prior to packaging located in Wisconsin. The sanitary conditions in the work environment were also suspect, as well. Managing product safety involves adopting proactive and reactive strategies to minimize the likelihood of delivery an unsafe or ineffective product and to avoid costly recalls.

Product security refers to the delivery of a product that is uncompromised by intentional contamination, damage, or diversion within the supply chain. Security problems can result from the actions of a third party that either disrupt the supply chain in order to destroy assets, as in the case of terrorist attack, or alter and misrepresent an individual product for economic gain, as in the case of counterfeiting (Sarathy, 2006). Since 2001, there has been increased attention towards developing strategies to safeguard the product supply chain against security breaches in order to avoid losses to human health and well-being, infrastructure, and supply chain assets. These approaches often involve strategies to reduce overall losses by identifying likely sources of threat and taking action to prevent or reduce the potential damage posed by that threat. Our focus herein is on security problems that compromise the product, resulting in the delivery of a product which is unsafe or ineffective. These problems would include deliberate substitution of materials/components, contamination or adulteration of a product, or misrepresenting a counterfeit product as authentic through counterfeited labeling, packaging or instructions. While any of these actions can lead to an unsafe or harmful product, they may also lead to a product that is ineffective. In the case of medical diagnostics, a compromised or counterfeit testing device may fail to accurately diagnose a medical condition, causing an error in the prescribed treatment and possible deterioration in the overall health of a patient. Thus, while the patient suffers no harm at the time of use, a counterfeit product can result in a delay in proper treatment, ineffective treatment, or incorrect treatment, any of which could endanger the health of a patient.

In this essay, we focus on five industries where product safety and security is most critical: food, pharmaceuticals, medical devices, consumer products and automobiles. Each of these industries has and continues to experience a growing number of product recalls that has caused product safety and security to emerge as a critical concern within the industry. Each of these industries shares two other important similarities. First, each industry has globalized with much sourcing of components and ingredients from low-cost global suppliers, increased outsourcing of production to foreign production facilities, and transportation and distribution within global markets. In each of these industries, recent safety problems can be traced back to changes in global supply chain systems. Second, each industry produces products which 
meet 'critical needs as defined by Nagurney et al. (2011). Specifically, all of these products, particularly food, pharmaceutical and medical devices, are necessary to sustain and prolong human life and well-being. Automobiles and consumer products, which include toys, electronics and household items, while not necessary to sustain human life, have certainly contributed to the quality of life and improved living standards enjoyed by much of the population. Problems with the safety or effectiveness of all of these products, no matter what the source of risk, have led to health problems, injury and even death.

\section{Interface between operations management and product safety and security}

Although product safety has traditionally been viewed as a technical problem in the domain of regulators, epidemiologists, design engineers, scientists, as well as quality management, safety engineering and ergonomics, there has been growing awareness that operations management can provide fresh and effective approaches to managing product safety and security. Lewis (2003) coined the term operational risk, which he defined as the potential for an operation to generate negative consequences for various external and internal stakeholders. Using case studies to investigate a theoretical model that integrated theories of operations management with risk management, he concluded that effective risk control is more similar to service quality management than process control. He advocated a risk control process that incorporates dimensions of prevention, mitigation and recovery.

Others later adapted risk management theory to address supply chain disruption. Using basic concepts of risk management where (1) sources of risk are identified; (2) potential consequences of those risks are assessed, and (3) the appropriate actions are determined to mitigate risk, Chopra and Sodhi's (2004) approach to supply chain risk involved stress testing to identify specific risks and tailoring strategies to adapt a risk mitigation approach for each specific risk. Kleindorfer and Saad (2005) used operations principles, such as supply chain optimization, supply chain agility, contingency planning, collaborative sharing of information in the supply chain, flexibility and modularity, and total quality management (TQM), among others, as the building blocks to effectively manage disruptive risk in a supply chain. While not a comprehensive list, others who use operations management principles to address issues of product security and safety include Lee and Whang (2005) who advocate the use of total quality management, Crosby's cost of quality paradigm and Six Sigma's Design Measure Analyze Improve Control (DMAIC) in order to design and operate better processes to assure supply chain security at lower cost. Kumar and Schmitz (2011) also use Six Sigma in the management of recalls. Tang (2008) and Pyke and Tang (2010) use continuous improvement as a foundation to their $3 \mathrm{R}$ approach (e.g. readiness, responsiveness, and recovery) in managing product safety and handling recalls.

Using an integrated operations management/risk management approach, we next describe 
the product safety and security risks in each of our five industries. We also discuss strategies to prevent and mitigate potential risks in these industries. While it is impossible to eliminate all hazards from ever reaching the market, we then discuss critical strategies and research directions for detecting and responding to safety and security failures. Many of these are relevant to the operations management literature.

\section{Product safety and security in critical industries}

Below we provide a brief description of product safety and security issues in five different industries - food, pharmaceuticals, medical devices, consumer products and automobiles.

\subsection{Food safety and security}

Unsurprisingly, the safety of food products has been a topic of debate for centuries. The first known law pertaining to the purity of food products, known as the "German Beer Purity Law" or Reinheitsgebot, dates as far back as 1516 (Dornbusch, 1997). Today we have a myriad of laws, regulations, standards, processes, tools and technologies intended to ensure food safety. Nevertheless, food safety scandals still occur on an all too regular basis. Table 1 presents some high profile food safety incidents that have occurred in several countries.

From a safety perspective, food supply chains have a number of vulnerabilities (Whipple et al., 2009). First, they deal with natural products, many of which are perishable and could become harmful to consumers if not managed in a timely and safe manner (Akkerman et al., 2010). Secondly, food supply chains tend to be long, global and highly interconnected, leading to greater risk exposure (Henson and Reardon, 2005; Roth et al., 2008; Trienekens and Zuurbier, 2008; Whipple et al., 2009). Third, food and beverage products are at risk of intentional or unintentional adulteration and could even be the target of terrorist threats (Wein and Liu, 2005; Whipple et al., 2009). According to Harl (2002), among seven general areas of vulnerability to terrorism in the US, five are related to the food supply chain. Careful management across the entire supply chain is necessary to ensure that products reaching the final consumer are safe to eat and drink.

Research by Voss et al. (2009) explores the tradeoffs among price, delivery, quality and safety in selecting suppliers in the food supply chains of the U.S. Their research concludes that, in general, safety considerations tend to be less important in selecting suppliers when compared to quality, delivery and price. They argue that this lower priority could be a factor behind the frequency of food safety incidents. However, their results also indicate that safety is more important under certain circumstances, particularly when products are sourced from abroad. Failures in food safety can have serious negative consequences not only for consumers, but also for the companies involved. The worst case scenario occurs when incidents lead to deaths or illness (Trienekens and Zuurbier, 2008). According to 
Thomsen and McKenzie (2001) millions of people around the world become ill every year as a result of unsafe foods. It has been estimated that in the U.S. alone, foodborne pathogens account for 76 million illnesses and 5000 deaths (Mead et al., 1999). Thomsen and McKenzie (2001) argue that human error and the limitations of food safety technology mean that, from time to time, consumers will face food safety risks. High profile incidents such as the Salmonella outbreak caused by peanut butter paste sold by the Peanut Corporation of America in 2008 (Layton and Miroff, 2009), or the adulteration of powdered milk with melamine in China in the same year (Spencer, 2009), have made the headlines due to their scale and severity. In both cases the consequences for those involved have been serious. The Peanut Corporation of America filed for bankruptcy in February 2009 (Layton and Miroff, 2009). In the Chinese case, Sanlu, the company responsible, has been closed down, the general manager and a number of company officials are in jail, and two have been sentenced to death (Spencer, 2009).

Most food safety incidents do not lead to death or illness, and in many cases products can be recalled before they reach the consumer. However, recalls can be complex and costly (Thomsen and McKenzie, 2001; Whipple et al., 2009), they can damage a firm's reputation (Hornibrook et al., 2005; Thomsen and McKenzie, 2001; Whipple et al., 2009), and ultimately affect the consumers' perception of an entire product category (Henson and Reardon, 2005; Trienekens and Zuurbier, 2008). All of these factors can contribute to shareholder losses. A study by Thomsen and McKenzie (2001) uses event analysis to evaluate the impact of product recalls on shareholder loses. They conclude that in cases where the product recalled poses a serious threat to consumers' health, there is a loss in shareholder wealth of between $1.5 \%$ and $3 \%$. However, they also conclude that recalls involving less serious infringements have no negative impact on shareholder wealth.

\subsection{Pharmaceutical safety and security}

Since the 1982 Tylenol deaths, public attention has been awakened to the vulnerability of pharmaceuticals in the supply chain. Pharmaceuticals are chemical substances used to diagnose, cure, treat or prevent disease or adverse medical conditions. They are among the most highly regulated of all products with many nations enforcing strict regulations on the marketing and sale of drugs. Since they are metabolized in the body, pharmaceuticals are subject to many of the same regulations found in the food industry. However, since a drug must be proven safe and effective in fulfilling its intended medical purpose, the approval process contains additional controls such as medical and scientific review, as well as clinical patient trials, to empirically test its effectiveness within the population. In medicine and the life sciences, drug safety means efficacy of the treatment, the absence of serious side effects, and the minimization of any interactions with other drugs that the patient may be taking. In this essay, we don't focus on these safety problems but, instead, consider safety and security problems that may occur in the supply chain. Specifically, we look at three problems: (1) contamination and substitution of both active and inactive ingredients within the global supply 
chain; (2) counterfeiting of drugs; and (3) the rise of secondary distributors. All of these problems have the potential to introduce patient safety risks into the supply chain and create costly liability, recalls and losses for the brand manufacturer. Several recent illustrations of these types of problems are presented in Table 2.

One trend in the pharmaceutical industry has been the global sourcing of both active and inactive ingredients from emerging economies where costs are lower. Further, the manufacture of generic drugs or those coming off patent are also more likely to be outsourced to manufacturers in developing countries. For example, in the last decade the value of India's production of both active ingredients and finished formulations for export has doubled (Grackin, 2008). The long supply chain, with sourcing, manufacturing, packaging and distribution occurring in different locations globally, has increased the risks of contamination or substitution of alternative ingredients, as in the case of the 2008 heparin accident (Blum, 2008).

Risk control through FDA regulation and inspections may be ineffective in detecting all the risks that can occur at each point in a multitier supply chain, particularly when the contamination is intentional or when there is fraudulent certification that the product has met all regulations and passed inspection (Tang, 2008). Grackin (2008) argues that risk prevention may be better served by using a total sourcing model, rather than the costbased models that are commonly used in sourcing decisions. She argues that a more comprehensive sourcing model would also consider the costs of risk management should the product be contaminated or adulterated. The high costs associated with supply disruption, product liability and recall might indicate that some low-cost suppliers are really high-cost suppliers when the expected costs of safety risk are factored in.

The second problem, counterfeiting, is subtly different from contamination since it refers to the intentional and fraudulent production of drugs for economic gain. In 2009, approximately 8.3 million doses of counterfeit pharmaceuticals were seized, and this amount was regarded as the tip of the iceberg of a growing problem in which counterfeiters seek to exploit the high cost of pharmaceuticals by offering them at lower prices (Jackson, 2009). In order to keep costs down, counterfeiters may use none or incorrect amounts of the active ingredient and then lace the drug with impurities or harmful substances. The risk to the patient may be harmful side effects or no treatment at all. In other words, the patient may think he/she is taking a drug to correct a health problem. However, since the counterfeit drug might lack correct concentrations of active ingredients, it may be akin to taking no drug at all. More than just a safety problem, some worry that counterfeit drugs could become a national security problem if terrorists are able to introduce counterfeit drugs into the supply chain (Health Industry Group Purchasing Association, 2004; Lawson, 2009). 
Table 1 - Selected high profile food safety incidents.

\begin{tabular}{|c|c|c|c|}
\hline Year & Incident & Description & Company \\
\hline 2011 & $\begin{array}{l}\text { E. coli } \\
\text { contamination of } \\
\text { bean sprouts }\end{array}$ & $\begin{array}{l}\text { As of this printing, an outbreak of a rare form of E. } \\
\text { coli killed } 37 \text { people and sickened more than } 3000 \\
\text { in Europe. European Union approved } 210 \text { million euros } \\
\text { ( } \$ 286.78 \text { million) in emergency aid for vegetable } \\
\text { farmers affected by the crisis. }\end{array}$ & $\begin{array}{l}\text { Sprout farm in northern } \\
\text { Germany near Hamburg }\end{array}$ \\
\hline 2008-2009 & $\begin{array}{l}\text { Salmonella } \\
\text { outbreak in } \\
\text { peanut butter } \\
\text { paste }\end{array}$ & $\begin{array}{l}\text { Contaminated peanut butter paste is linked to nine } \\
\text { deaths and } 637 \text { cases of Salmonellosis in the U.S. and } \\
\text { Canada with thousands more illnesses suspected. The } \\
\text { incident triggered the largest product recall in U.S. } \\
\text { history affecting nearly } 4000 \text { products (Layton and } \\
\text { Miroff, 2009). }\end{array}$ & $\begin{array}{l}\text { Peanut Corporation of } \\
\text { America }\end{array}$ \\
\hline 2008 & $\begin{array}{l}\text { Dioxin in Irish } \\
\text { pork dioxin }\end{array}$ & $\begin{array}{l}\text { Large international recall of Irish pork products due to } \\
\text { contamination with dioxin. Pork supplies to a total of } \\
23 \text { countries was affected, } 13 \text { within the European } \\
\text { Union (EFSA, 2008; Hornibrook et al., 2005). }\end{array}$ & $\begin{array}{l}\text { Millstream Power } \\
\text { Recycling Limited }\end{array}$ \\
\hline 2008 & $\begin{array}{l}\text { Melamine in } \\
\text { Chinese milk } \\
\text { products, } \\
\text { including milk } \\
\text { powder }\end{array}$ & $\begin{array}{l}\text { Contamination of milk and infant formula, as well as } \\
\text { other milk-based products due to adulteration with } \\
\text { melamine. An estimated 300,000 illnesses were } \\
\text { reported and six infants died (Roth et al., 2008). }\end{array}$ & $\begin{array}{l}\text { Chinese milk producers } \\
\text { Sanlu Mengniu, Yili, } \\
\text { and Yashili }\end{array}$ \\
\hline $1986-1987$ & Mad cow disease & $\begin{array}{l}\text { Epidemic of Bovine Spongiform Encephalopathy } \\
\text { (BSE) } \\
\text { or "Mad Cow" disease in U.K. was suspected to be the } \\
\text { cause of variant Creutzfeldt-Jakob Disease (CJD) which } \\
\text { affected hundreds of people (Colchester and } \\
\text { Colchester, 2005). }\end{array}$ & $\begin{array}{l}\text { Multiple producers in } \\
\text { U.K. }\end{array}$ \\
\hline 1858 & $\begin{array}{l}\text { Arsenic poisoning } \\
\text { in sweets }\end{array}$ & $\begin{array}{l}\text { An accidental contamination of sweets with } \\
\text { arsenic poisoned more than } 200 \text { people and } \\
\text { resulted in about } 20 \text { deaths. This incident led to } \\
\text { the passage of the Pharmacy Act } 1868 \text { in the UK } \\
\text { and legislation regulating the adulteration of } \\
\text { foodstuffs (Sheeran, 1992). }\end{array}$ & Bradford, England \\
\hline
\end{tabular}

Sources of the problem are very much related to changes in the supply chain. They include internet pharmacies and sellers, often located in other countries, that distribute and sell counterfeit drugs. As discussed above, with much manufacturing outsourced, there are a number of unscrupulous manufacturers, many located in India, China and Southeast Asia, who will produce the counterfeit drugs and package them so they look authentic. Group purchasing organizations (GPOs) seeking lower costs for volume purchases may fall prey to counterfeiters and bring them into hospitals and other health care organizations. Another source of counterfeiting includes hackers who breach the proprietary data of pharmaceutical corporations to steal formulas and logistics strategies. Finally, well-publicized shortages of drugs, like vaccines, may cause legitimate health care organizations to seek alternatives to name brand products and unintentionally procure counterfeit drugs (Grackin, 2008; Lawson, 2009). 
Current approaches to combat counterfeiting are adopted from methods used to track inventory through the supply chain. Some states already require each drug to have a unique electronic pedigree which can be used to track the drug through the supply chain and which can identify the path of the drug from manufacture to distribution and retail. The ePedigree coupled with the use of smart devices, such as strategically placed sensors and RFID readers throughout the supply chain, is currently viewed as possibly the most effective means of combating counterfeiting (Health Industry Group Purchasing Association, 2004; Lawson, 2009).

Table 2 - Selected high profile pharmaceutical safety incidents.

\begin{tabular}{|l|l|l|l|l|}
\hline Year & Product & \multicolumn{1}{|c|}{ Problem description } & Manufacturer \\
\hline Ongoing & Viagra & $\begin{array}{l}\text { Pharmaceutical manufacturers in China and India have been involved } \\
\text { in the illegal manufacture and import of counterfeit Viagra into the } \\
\text { US. These illegal drugs often lack the active ingredient and may } \\
\text { include harm-ful ingredients as fillers. Results have included } \\
\text { hypoglycemia, stroke and even death. 57\% of all counterfeit drugs } \\
\text { seized is Viagra (Jackson, 2009) }\end{array}$ & Pfizer \\
\hline 2009 & Tylenol & $\begin{array}{l}\text { Reports of a musty, mildew-like odor associated with the analgesic } \\
\text { were believed to be the result of a chemical used to treat wood pallets } \\
\text { that transport and store packaging materials. The pallets were } \\
\text { believed to have originated in the Dominican Republic and were } \\
\text { then used to ship product from the manufacturing facility in Puerto } \\
\text { Rico into the U.S. The odor was associated with gastrointestinal upset. } \\
\text { A voluntary recall was issued (Rogers, 2009). }\end{array}$ & McNeil \\
\hline 2008 & Heparin & $\begin{array}{l}\text { The active ingredient in heparin, which is derived from pig intestines } \\
\text { was contaminated with over-sulfated chondroitin after a virus } \\
\text { decimated Chinese pig herds. The contamination was blamed for 81 } \\
\text { deaths and over 400 injuries, including allergic reactions. A recall was } \\
\text { issued in 2008 (Blum, 2008). }\end{array}$ & Baxter \\
\hline
\end{tabular}

The third problem of secondary distribution channels is also related to the growing complexity of the supply chain. While not necessarily illegal, secondary distributors may present some safety risks. Secondary distributors represent another supply path in an already complex supply chain. They often purchase product from a source other than the manufacturer, such as another distributor, and then sell the product directly to a health care organization or a customer. Often when manufacturers offer discounts to meet sales targets or to reduce their inventories, secondary distributors may begin to stockpile drugs and later sell and divert them back into the primary distribution system. There are three possible safety problems with the diversion (Health Industry Group Purchasing Association, 2004). One is that secondary distributors may stockpile drugs that are near their expiration date and then introduce them back into the supply chain at lower prices. Second, the distributors may not have proper storage conditions for drugs which are sensitive to high temperatures and, thus, compromise the safety and effectiveness of the drug. Third, the distributors may stockpile critical drugs and, should the drug be in short supply, they will gouge the market with inflated prices. The Health Industry Group Purchasing Association (2004) noted 
that this was the case in the 2000 flu vaccine shortage where a dose sold at five times its usual price. While there may be nothing illegal with this arbitrage behavior, it is certainly unethical. It also leads to conditions where counterfeiters could easily enter the market and infiltrate the primary supply chain by offering the critical drug at cheaper prices and in abundant supply. Thus, some of the challenges associated with balancing supply with demand in the pharmaceutical supply chain can be traced back to the influence of the secondary distributors.

\subsection{Medical device safety and security}

Rapid technological developments in the medical products industry have created portfolios of innovative and enhanced pharmaceutical products and medical devices that have helped to improve human health and increase life expectancy. Panescu (2006) attributes reported overall reductions in the rate of mortality and complications due to heart attacks, stroke, diabetes and cancer reported between the years 1980 and 2000 to technological advances in medical devices and diagnostics. Yet despite this progress, there is growing concern regarding the safety of these devices as evidenced by a sample of some wellpublicized product failures illustrated in Table 3 . These recalls range from the most serious Class I recalls where the FDA has assessed a reasonable likelihood of serious death or injury to voluntary recalls where the manufacturer has issued the recall in response to reports of failure and safety risk from the field. A database of these and other recalls can be found on the FDA's website www.fda.gov/MedicalDevices/Safety/RecallsCorrectionsRemovals.

In this section we focus on medical devices, a product category which consists of a broad array of diagnostic and therapeutic medical products. Although medical devices include some very simple products, such as gauze and bandages, the most sophisticated medical devices are highly engineered products that increasingly integrate mechanical, electrical and software systems to produce physical changes in the structure or function of the body. Since the type and nature of safety risk can vary widely, depending on the device category, the FDA recognizes three general classes of medical device based on the level of risk that they present. Class I devices are regarded as lower risk products, and hence, subject to the least control. These devices aren't intended to support or sustain life and would include products such as temperature monitors and hand-held surgical instruments. Class II devices, such as infusion pumps and ultrasound sensors, may be subject to additional controls, such as performance standards to ensure that they reliably operate at an effective level. Safety problems could be created if these products malfunction or fail to perform reliably. Finally, Class III devices are subject to the highest regulation because they often support and sustain human life and pose serious risks to safety should they be found defective or fail to perform reliably. Examples of Class III devices include sophisticated therapeutic products like implantable cardioverter defibrillators (ICDs), pacemakers and vascular stents which are implanted into the body, as well as diagnostic devices such as HIV test kits. Although errors 
can occur during the design, manufacture, storage, transportation or use for any class of device, it is usually accidents or failures associated with the Class III devices that receive public attention. Note that other countries in Europe and Canada define these categories in different ways so while the various typologies are similar, there is no uniform classification system (Department of HHS FDA, 2009).

Like the pharmaceutical industry, the U.S. medical device industry has been the source of a number of important medical innovations. With a market size of over $\$ 100$ billion that is fueled by millions of dollars of venture capital invested annually, the industry has witnessed a rapid pace of technological development as evidenced by its high R\&D intensity and the thousands of patents issued each year (Chatterji, 2009). Yet this reliance on innovation has, paradoxically, presented some safety risks. Three risks are discussed below. One risk is balancing innovation with safety in the new product development process. The second are the risks presented by an increasingly global supply chain. The third is counterfeiting. As with pharmaceuticals, counterfeiting in the medical device industry poses explicit risks to safety and security.

One problem for the industry has been a continual struggle to produce a constant stream of innovative products that meet market demands and fuel revenue growth while still complying with the FDA regulations for testing and review necessary for premarket approval. Complaints that the regulatory approval process actually stifles innovation because it costs too much and takes too much time in the developmental cycle are countered by statistics on the high number of recalls in the medical device industry (McKinney, 2011). Yet the financial consequences of a product recall may be less severe for the firms in the medical device industry than in other industries. In an event study of product recalls in the medical device industry, Thirumalai and Sinha (2011) found that at an aggregate level, financial market penalties for a recall announcement weren't statistically significant, regardless of the type of recall. In explaining this surprising result, the authors posited that perhaps as technologies are introduced and evolve, the market learns to expect recalls. 
Table 3 - Several high profile medical device failures.

\begin{tabular}{|c|c|c|c|}
\hline Year & Product & Description of problem & Company \\
\hline 2011 & $\begin{array}{l}\text { Balloon } \\
\text { catheter }\end{array}$ & $\begin{array}{l}\text { A design defect was discovered in the catheter whereby after } \\
\text { insertion, it could accidentally fracture or the bond could start } \\
\text { peeling. The retained fragments of the device could injure arteries } \\
\text { and result in death. Surgical intervention could be required to } \\
\text { remove the fragments. Although no injuries were reported, the } \\
\text { result was a Class I recall of less than } 15,000 \text { units in the U.S. and } \\
\text { about } 3000 \text { in other countries. }\end{array}$ & AngioScore \\
\hline 2011 & Surgical graft & $\begin{array}{l}\text { After facing } 3000 \text { lawsuits over problems with a hernia repair graft, } \\
\text { the company discovered several lots of surgical graft used in } \\
\text { repairing abdominal walls were contaminated with elevated } \\
\text { endotoxin levels. No injuries were reported, but there was a risk for } \\
\text { serious infection, septic shock, and death. }\end{array}$ & XenMatrix \\
\hline 2009 & $\begin{array}{l}\text { Infant } \\
\text { incubator }\end{array}$ & $\begin{array}{l}\text { Although the product originally manufactured by Hill-Rom was } \\
\text { discontinued in } 1998 \text {, Draeger later acquired Hill-Rom and } \\
\text { discontinued all product service and support in } 2003 \text {. Yet the } \\
\text { incubator was still in use. In this accident the device overheated } \\
\text { and was responsible for a fire that injured an infant receiving } \\
\text { oxygen. The result was a voluntary recall of over } 6000 \text { units. }\end{array}$ & Draeger Medical \\
\hline 2008 & Heart stent & $\begin{array}{l}\text { A design defect was discovered when the tip detached from the } \\
\text { delivery system while the stent was being threaded into place during } \\
\text { insertion. Result was increased procedure time, possible injury to } \\
\text { vessel walls, stroke or emergency surgery. Voluntary recall of about } \\
2700 \text { stents. }\end{array}$ & Boston Scientific \\
\hline 2007 & ICD defibrillator & $\begin{array}{l}\text { The lead in the defibrillator was found to fracture which could cause } \\
\text { the device to issue unnecessary shocks or not operate at all. } \\
\text { Although } 13 \text { deaths and multiple injuries were blamed on the lead, } \\
\text { a voluntary recall was issued for } 268,000 \text { units. }\end{array}$ & Medtronic \\
\hline
\end{tabular}

Some safety hazards posed by complex new technologies may be difficult to anticipate during development, and may not be realized until the device is actually in use (Maisel, 2005). Mojdehbakhsh et al. (1994) suggest there may be different phases in the life-cycle of a device where different types of safety problems may arise. Like the other industries we review, some problems occur prior to use. They may include errors, such as contamination or inadequate sterilization, that might arise during manufacturing, packaging, transportation, storage, and handling. Some risks might occur during implantation such as the heart catheter whose tip detaches. Other problems may arise after implant and during normal use when the patient is ambulatory, such as a pacemaker which becomes unreliable or malfunctions. Cases where the device must be removed also present additional risks. Maisel (2005) reported that more people were injured in the extraction of the ICD with a lead failure than were injured by the failure itself. Singer (2010) reported that one of problems associated with the Johnson \& Johnson recall of its hip replacement implant was that its 
high failure rate might require patients to undergo additional costly and painful surgeries to remove the failed device and to replace it with another. Thus, anticipating all possible failures in the lifecycle of a device can be difficult when the technology is new and still in development.

A second problem is that the medical device industry, like others, is rapidly globalizing with the volume of imported products and components growing by an average of $25 \%$ annually over the period of 2001-2007. Likewise, the number of foreign Classes Iand II medical device manufacturing facilities nearly doubled during this same time period with an estimated $70 \%$ of medical device makers and pharmaceuticals engaged in manufacturing arrangements with China (Department of HHS FDA, 2009; Rhea, 2007). Further, these foreign companies are expanding their role in the medical device value chain. Not content to just remain suppliers of components or contract manufacturers, several companies in China are also developing technological expertise and are poised to become global innovation leaders in design and development over the next decade (Barr, 2011). Although the FDA is responsible for assuring the same quality standards are used for qualifying foreign manufacturing facilities as those used in the U.S. safety and effectiveness of that medical devices, the globalization of the industry makes this task more daunting (Tang, 2008).

All countries haven't reached the same maturity in enforcing the same sets of standards or regulations used by the FDA. For instance, prompted by a series of product failures, China began a series of more comprehensive changes to their medical device regulation in 2008 (Yang, 2008). A key problem was harmonizing the various local standards used by provincial regulatory bodies with new central level requirements. This was seen as a critical step before attempting to conform to U.S. and European standards. As new devices are designed, developed, manufactured and distributed all over the world, regulation and assurances of product safety will become increasingly difficult to enforce.

The third source of safety problems is the growing rate at which counterfeit devices are sold for economic gain. Increasing accessibility to technology that can be used to manufacture devices and print labels means that counterfeiters can distribute products that are similar to authentic products in every respect, including packaging, labeling, instructions and even certification markings. Since the counterfeits are so realistic, health care providers may inadvertently use them, not suspecting a problem until there is a malfunction or a patient injury. The WHO estimated that $8 \%$ of the total medical device market is counterfeit. The dangers of counterfeit products include safety risks to patients due to the use of inferior or toxic materials as well as the economic risks to the genuine manufacturer who may face legal liabilities, loss of revenue and harm to the product brand (Lancaster, 2010). 
devices command make it economically lucrative for a third party manufacturer to produce counterfeit products at lower costs, and then turn around and sell the products on the Internet or through online auctions at lower prices than the true manufacturer could. Second, the long and complex supply chains provide many opportunities for counterfeit items to enter. Counterfeiting can occur at the component level or at the finished good level and can reach the market through a distributor, wholesaler or even a retailer. Difficulties in tracing the supply path, particularly as it passes through international trade zones, makes counterfeiting a crime that is difficult to detect. One suggested solution is the adoption of imaging and tracking technologies that have been used in inventory management. Technologies such as barcoding, holograms, OCR and RFIDs can be used to capture information about the product, verify its authenticity and monitor it through all stages of the supply chain (Lancaster, 2010). Congress has authorized the FDA to establish a unique device identification system (UDI) for medical devices that would uniquely identify the product through distribution and use (Department of HHS FDA, 2009).

\subsection{Consumer product and motor vehicle safety and security}

Recently, less public attention has been directed towards the safety of consumer products such as toys, electronics and household items relative to the attention that products such as food and pharmaceuticals have received. Motor vehicles, however, have received considerable attention lately due to a series of recent large recalls by Toyota and other car manufacturers. In the United States, responsibility for the safety of consumer products, with the exception of food, pharmaceuticals and automobiles, falls to the U.S. Consumer Product Safety Commission (CPSC) which regulates the sale and manufacture of more than 15,000 different consumer products. Authority for the CPSC is provided in the 2008 Consumer Product Safety Improvement Act (Flaherty, 2008). This act was the result of a spike of 473 consumer products recalled in 2007 in what is referred to as the "Year of the Recall." Since 2011, CPSC has also maintained a public database of public complaints of safety problems connected with any of the 15,000 kinds of consumer goods regulated by the CSPC (www.saferproducts.gov). This database provides a growing and potentially rich database for understanding trends in consumer product safety. Authority for European consumer product safety is provided under the framework of the General Product Safety Directive. A rapid alert system, RAPEX, allows for rapid exchange of information on dangerous consumer products between the member countries and the European Commission, with the exception of food, pharmaceutical and medical devices which are covered under other mechanisms. In the U.S., the National Highway Traffic Safety Administration (NHTSA) is responsible for writing and enforcing safety, theft-resistance, and fuel economy standards for motor vehicles. NHTSA maintains the National Center for Statistics and Analysis database and the Fatality Analysis Reporting System (FARS) which is a resource for traffic safety research throughout the world. Table 4 below presents recent high profile consumer product and motor vehicle safety events. 
Table 4 - Selected high profile consumer product safety incidents.

\begin{tabular}{|c|c|c|c|}
\hline Year & Product & Recall description & Company \\
\hline 2008-2011 & Automobiles & $\begin{array}{l}\text { Three separate recalls (floor mats, } \\
\text { accelerator pedal, and unrelated anti-lock } \\
\text { brake) of automobiles by Toyota Motor } \\
\text { Corporation after reports of unintended } \\
\text { acceleration. More than } 9 \text { million cars } \\
\text { recalled worldwide. }\end{array}$ & Toyota \\
\hline $2006-2011$ & $\begin{array}{l}\text { Notebook } \\
\text { computer } \\
\text { batteries }\end{array}$ & $\begin{array}{l}\text { More than four million notebook computer } \\
\text { batteries made by Sony were recalled after a } \\
\text { number of instances where the batteries } \\
\text { overheated or caught fire. Most of the } \\
\text { defective notebooks were sold in the U.S. } \\
\text { However, some one million faulty batteries } \\
\text { could still be in use elsewhere in the world. }\end{array}$ & $\begin{array}{l}\text { Sony, Dell, Apple, } \\
\text { Toshiba, Hitachi, IBM, } \\
\text { among others }\end{array}$ \\
\hline 2011 & $\begin{array}{l}\text { Swimming pool } \\
\text { drain covers }\end{array}$ & $\begin{array}{l}\text { The CPSC recalled more than } 1 \text { million } \\
\text { swimming pool drain covers currently } \\
\text { installed at thousands of public and private } \\
\text { pools across the country that can trap and } \\
\text { drown swimmers. }\end{array}$ & $\begin{array}{l}\text { Eight U.S. } \\
\text { manufacturers of pool } \\
\text { drain covers }\end{array}$ \\
\hline 2010 & Children's toys & $\begin{array}{l}\text { Safety concerns caused the recall of more } \\
\text { than } 11 \text { million tricycles, toys and high chairs } \\
\text { due to safety hazards, as well as } 100,000 \\
\text { toys due to a choking hazard. }\end{array}$ & Fischer Price/Mattel \\
\hline 2009 & $\begin{array}{l}\text { Roman and roller } \\
\text { window shades }\end{array}$ & $\begin{array}{l}\text { More than } 50 \text { million roman and roller shades } \\
\text { were recalled due to a strangulation hazard } \\
\text { for children. Five children have died of } \\
\text { strangulation and } 16 \text { others have been nearly } \\
\text { strangled since } 2006\end{array}$ & $\begin{array}{l}\text { Wal-Mart, JC Penney, } \\
\text { Pottery Barn, West } \\
\text { Elm, Ace Hardware, } \\
\text { Big Lots, Ross and The } \\
\text { Land of Nod }\end{array}$ \\
\hline $2006-2007$ & Children's toys & $\begin{array}{l}\text { More than } 20 \text { million Chinese-made toys, } \\
\text { were recalled due to possible lead-paint } \\
\text { hazards for children and the use of strong } \\
\text { magnets that may detach and present a } \\
\text { swallowing hazard }\end{array}$ & $\begin{array}{l}\text { Fischer Price/Mattel, } \\
\text { Mega Toys, and others }\end{array}$ \\
\hline 2006 & Trucks & $\begin{array}{l}\text { Recall of nearly } 8 \text { million pick-up trucks and } \\
14 \text { other models built in } 1988-1993 \text { for a } \\
\text { short circuit in the ignition switch that could } \\
\text { lead to a fire in the steering column. }\end{array}$ & Ford \\
\hline
\end{tabular}


While problems with consumer product safety have continued to increase in recent years, little academic research has directly addressed the operational and supply chain issues that lead to unsafe products and recalls with the exception of Kumar and Schmitz (2011). In the 1980s and early 1990s, consumer product safety research focused on manufacturing issues within the factory including factors such as quality control and, to some extent, product design. Recently, safety problems with consumer products can be traced to changes in global production systems and the increasing complexity of global supply chains - especially supply chains that cross emerging markets such as China. On the other hand, studies of the trends in automobile recalls in the U.K. between 1992 and 2002 demonstrate enormous differences between car manufacturers that are linked to geography. Specifically, European and American manufacturers have recall rates that are nearly three times higher than those of manufacturers in East Asia (Bates et al., 2007). Safety and security issues for consumer products can be broadly attributed to three sources: (1) supply chain-related issues; (2) design-related issues; and (3) manufacturing-related issues, described below.

As consumer product companies have shifted large segments of their production overseas, it has been more difficult to maintain the safety of their products. This is especially true for recent high profile recalls of products made in Asia. For example, in 2010, more than $90 \%$ of toys were imported from Asia, especially China. The electronics industry is dominated by a few global firms, but most all of them manufacture in low-wages countries in Asia. These devel opments have placed a premium on the ability of governments to work together in partnership to advance consumer product safety. In 2008, the European Union, U.S., and China launched a trilateral approach to product safety designed to build mutual trust and develop a coordinated response to product safety concerns, as well as keep to product safety at the top of the international political agenda. International priorities include product traceability, convergence of safety requirements, advice to manufacturers, and joint enforcement actions. The particular challenges of maintaining product design quality and safety in international production networks while, at the same time, trying to cut costs and shorten the concept-to-market time have been addressed (Zhu et al., 2009, 2008). Many attribute the massive 2010 Toyota recall to the overly rapid expansion of Toyota's international production networks, and a focus on the bottom line rather than on product quality and safety (Minhyung, 2010).

Another stream of research has attempted to understand which parts of the value chain are most responsible for safety problems by distinguishing between design-related and manufacturing-related recalls. Design defects include such causes as the use of small detachable parts that pose a swallowing threat or engineering design defects that may cause product overheating. Manufacturing defects include the use of parts contaminated by toxic materials or manufacturing errors that lead to malfunction or explosion. Such problems would include use of an inferior material instead of a specified material, poorly fitting parts and improper assembly, or batteries that overheat. The use of lead paint would also be considered 
a manufacturing-related safety problem since it was not part of the intended design. Research by Chiang et al. (2001) examined the product design and manufacturing literature to understand why consumer products of daily use fail to provide the intended function to users' satisfaction. Other researchers have analyzed recall data available from the CSPC and found a steady increase in recalls, and also that design problems have been responsible for the majority of toy recalls (Hora et al., 2011). According to some authors, design-related recalls are increasing faster proportionately, than manufacturing-related defects regardless of where the manufacturing occurs, although there have been some challenges to this result (Bapuji and Beamish, 2007; Bapuji et al., 2007; Dowlatshahi, 2000). For example, over the period 19882007, the average annual number of distinct products recalled in the toy industry due to design flaws was approximately 25 compared with only two that could be directly attributed to manufacturing-related problems (Bapuji and Beamish, 2007).

As noted above, many of the defects that result in safety problems for consumer products can be attributed to a lack of quality processes during product development, including engineering and design (White and Pomponi, 2003). While a number of papers appeared in the late 1980s and early 1990s addressing design issues and safety, many were published in the ergonomics literature. Principles of ergonomics can contribute directly to the resolution of a product safety problem. A methodology has been developed for applying ergonomic factors to the resolution of safety issues concerning the design, manufacture and use of consumer products (Ramsey, 1985; Sagot et al., 2003). Several papers have investigated the root causes of accidents in order to estimate the percentage of accidents that could be prevented or mitigated by changes in design or the design process (Hale et al., 2007; Kinnersley and Roelen, 2007; Kirwan, 2007). Some authors have tried to present a coherent and systematic approach for considering possible safety problems and how to avoid them (Fadier and Ciccotelli, 1999; Kjellen, 2002). Others explored whether design processes that are successful in one industry can be transferred to other industries (Drogout et al., 2007).

A variety of methodologies and systems have been suggested for integrating safety into the design process (Fadier and De la Garza, 2006; Hasan et al., 2003). Some researchers have addressed user-focused design methodologies, taking into account end-user characteristics, interactions with work environment characteristics, and task cognitive requirements (Blaise et al., 2003; De la Garza and Fadier, 2005; Fadier et al., 2003). Frameworks for implementing user-focused design have also been developed (Fadier and De la Garza, 2006). Quality function deployment, a tool adapted from operations management, has also been proposed as an approach for considering multiple objectives, including safety, in establishing design requirements (Karsak, 2004). A new concept, Prevention through Design, or PtD, has been introduced as a national research initiative by the National Institute for Occupational Safety and Health. Prevention through design is a risk mitigation strategy where hazards and risks are virtually "designed out" of a product. Prevention by design was the topic of a 2008 workshop 
that addressed a variety of issues from building the business case for PtD to the development of PtD tools and processes, and methodologies for PtD research (Alston, 2008; Creaser, 2008; Gambatese, 2008; Manuele, 2008; Schulte et al., 2008; Zarges and Giles, 2008). Finally, some researchers have looked specifically at materials considerations in product design (Karana et al., 2008).

Manufacturing-related problems that have the potential to impact human health have not been reported as frequently for consumer products such electronics or toys as they have for other products. As a result, manufacturing-related safety problems have not received as much attention in the academic literature. Recently, however, as supply chain complexity has increased, researchers are refocusing attention on manufacturing-related problems caused by outsourcing the manufacturing task (Tang, 2008). Several safety problems with products manufactured in developing regions of the world are linked to intentional actions by a supplier or outsourcer to increase profits at the expense of safety. Other manufacturing-related safety defects are largely unintentional problems in the specified manufacturing process that are not recognized until the product is in the hands of the consumer. Safety issues related to manufacturing defects are generally subsumed in larger quality issues which have been wellstudied. Recently, attention has been focused on the relationship between lean manufacturing and increased levels of safety concerns. Lean manufacturing promises a low-cost, highefficiency production line but also brings a risk of quality control and safety issues. As product lines become more technologically advanced, it is easier for problems to go unnoticed until huge volumes have been shipped.

\section{Challenges and directions for future research}

The growing complexity of global supply chains related to off-shoring and outsourcing, coupled with the constant development of new products, processes and technologies, have created product safety and security challenges in the industries that we have just discussed. However, these challenges are opening new avenues for operations management research in addressing critical issues that impact product security and safety. From our review of the extant literature, we have identified four key areas for further research that share commonality and criticality across all of the product groups we investigated: (1) collaborating with governments in developing new regulatory mechanisms and standards that incentivize safety; (2) better tools and methodologies for managing information during the lifecycle of the product from design through disposal; (3) technologies for tracing products across the global supply chain and managing recalls; and (4) building supplier relationships as a critical element of a product safety risk management strategy.

\subsection{Regulation and standards}

Any risk management strategy for assuring product safety throughout the supply chain must address incentives (or disincentives) for firms in implementing policies, processes, and 
practices that promote the safety of products. Governments, international organizations and industry associations are seldom considered as collaborators in supply chain safety, but partnerships between business and government agencies will be required to improve safety and security in the supply chain (Sarathy, 2006). While the terms "regulation" and "standards" are often used interchangeably, there are some differences. Regulations establish government agencies, such as the U.S. Consumer Products Safety Commission (CPSC), the Food and Drug Administration (FDA), and the National Highway Transportation Safety Administration (NHTSA) with the responsibility for performing critical duties, such as approving products as safe and effective prior to entering the market, inspecting manufacturing facilities, and pursuing recalls. These agencies assure that firms meet basic rules for safety, and they also possess the authority to impose sanctions or fines when they discover violations or non-compliance.

Standards are established norms or codified requirements for a product, such as material specifications or technical standards for performance. Standards may be developed by regulatory agencies, public organizations or industry associations. Many industry standards are voluntary meaning that compliance is expected and supervised by independent boards, but there are no legal sanctions for non-compliance. The most common of the public standards are those promoted by the International Standards Organization (ISO), most notably the ISO 9000 (1) series of quality standards which are industry independent, and the ISO 22,000 standard which focuses specifically on the management of safety across supply chains (Luning et al., 2006; Trienekens and Zuurbier, 2008). Compliance with FDA's Good Manufacturing Practice (GMP) is a requirement for manufacturers of pharmaceuticals, medical devices (Classes II and III) and food. While different GMP guidelines are used by the World Health Organization (WHO), the European Union, Canada and many other countries, the basic concepts are similar (Aruoma, 2006; Trienekens and Zuurbier, 2008). According to many guidelines, compliance with GMP means that the manufacturer must effectively meet ISO 9000 standards in assuring that an adequate quality system is in place to assure that proper production and testing processes are in place for producing quality products (ERG, 2006).

The benefits of standards are controversial with some arguing that they promote better product quality and signal good management while others argue that some firms are minimalists and will do only what is necessary to meet standards. Numerous studies of the benefits of ISO 9000 have been inconclusive and only intensified the debate about the effectiveness of standards (Anderson et al., 1999; Corbett et al., 2005; Sroufe and Curkovic, 2008; Terziovski et al., 1997). In discussing private standards for food safety, Trienekens and Zuurbier (2008) argue the benefits of such standards in serving four purposes: (1) to improve suppliers' standards and avoid product failure; (2) to eliminate multiple audits across the supply chain; (3) to transfer specific demands to parties upstream in the chain; and (4) to provide traceability in cases of food incidents. Henson and Reardon (2005) argue that, in addition to ensuring traceability and safety, private standards can also be used as a form of 
differentiation, becoming a "major competitive instrument". However, others argue that standards are nothing more than a tariff because the cost of implementation and accreditation is a major barrier, particularly for small companies or for those based in developing countries with limited access to resources (Trienekens and Zuurbier, 2008). For example, Liu (2004) argues that many local manufacturers in China fail to meet established GMP standards, but they do have lower cost structures and other capabilities that could make them good candidates for outsourcing and contract manufacturing of Class I medical devices.

Another major international challenge, given the complexity of global supply chains, has been the harmonization of standards and regulations both within countries and across countries to ensure that safety management practices are applied consistently across the supply chain (Aruoma, 2006; Department of HHS FDA, 2009). On one hand, harmonized standards and regulations would lead to decreased bureaucracy for companies that wish to meet safety requirements and be able to market their products in different countries. But this may not be easy, as often standards must be first harmonized internally within a country. China found that just harmonizing regulations across different provinces, as well as across different government agencies, delayed the globalization of its medical device industry (Yang, 2008).

Further, the proliferation of standards and the bureaucratic burden imposed on suppliers can make find it difficult to comply (Trienekens and Zuurbier, 2008). As manufactured products become technically more complex, there are an increasing number of standards addressing different systems embodied in the product that must be considered. For example, the ICS 11.100 and 11.040 standards specify ISO requirements for medical devices. However, many devices also use electrical and software systems. IEC 60,601 standards provide the requirements for medical electrical equipment while IEC 62,304 specifies standards for medical software. ISO 13,845 represents the requirements for the design and manufacture of medical devices (Higson, 2002). This example illustrates that different standards might address different systems or modules of a single product. McKinney (2011) argues that this proliferation of standards coupled with FDA requirements for market approval can slow down the pace of innovation in the medical device industry, thus creating economic losses for the industry as well as societal losses.

While regulation and standards are needed, there are questions as to whether this approach provides effective incentives for ensuring product safety in the supply chain. One stream of research addresses the impact of tort liability in the U.S. and Europe on product and process design. It questions the assumption that fear of tort liability influences companies to emphasize safety and minimize risk in designing or developing a new product (Baram, 2007). The 1976 Medical Device Amendment provides that, unlike drugs, a medical device manufacturer couldn't be sued in state court by patients alleging injury due design defect or failure to warn if the device had received marketing approval from the FDA. This was the basis 
for the dismissal of 1000 cases involving an ICD lead which was recalled from the market in 2009 (Curfman et al., 2009). Thus, many question the effectiveness of tort liability alone in ensuring safe products.

Questions also arise as to whether regulations will be sufficient to address potential safety issues relating to current and future products that derive from new technologies or industries (e.g. biotechnology or genetically modified products). Thus, there has been limited research recently on new approaches such as co-regulation and taxation that could be more effective (Magat and Viscusi, 1992; Magat and Moore, 1996). Earlier work by Johnson (1982) addressed cost-benefit analysis and the optimal level of consumer product safety, including voluntary standards. Further, while the use of standards and regulations is accepted practice in the developed world, as globalization moves the base of manufacturing in developing countries, studies have looked at the impact of safety standards on the start-up and production costs for small and medium-sized firms. Research has suggested that policy solutions might focus on subsidies or public support programs that offset the cost disadvantage that arises (Maskus et al., 2005). Further work is needed in the interface of operations and policy to determine the most effective incentives for ensuring product quality and safety in the supply chain.

\subsection{Product lifecycle management}

Product lifecycle management refers to the process of managing the entire lifecycle of a product from conception through design and manufacturing, including service and disposal. As a risk prevention tool, one key challenge with lifecycle management is to manage all data relating to the design, production, support and ultimate disposal of manufactured goods so as to improve the safety and quality of the product. The expression of this task varies depending on product type. Some approaches are process-based. For example, managing food safety risks across the supply chain requires documented policies and procedures that describe how to deal with the product throughout its lifecycle (Creedle, 2007). One of the most common tools serving this purpose for food products is Hazard Analysis and Critical Control Points (HACCP) (Akkerman et al., 2010; Aruoma, 2006; Creedle, 2007; Henson and Reardon, 2005; Trienekens and Zuurbier, 2008). HACCP was originally developed by NASA and Pillsbury to control the quality of food supplied to the manned space program. It is based on an adaptation of the Failure Mode and Effect Analysis (FMEA) technique, an approach commonly used in engineering applications. HACCP follows a systematic approach to identifying, evaluating and controlling those steps in the process that are critical to food safety (Akkerman et al., 2010; Sperber and Stier, 2009). HACCP is at the center of many safety assurance systems such as the Codex Alimentarius, both EU and US food legislation, ISO 22,000 and most private standards (HACCPEuropa, 2011; Trienekens and Zuurbier, 2008).

A related tool for safety analysis used in the management of the lifecycle in medical devices is hazard analysis. The process starts with a preliminary hazard analysis that is intended to 
identify the scope and nature of hazards that might arise in critical design areas. Subsequent analyses examine the hazards that may arise during storage, transportation or use; hazards that arise due to technical malfunction or failure of the device; and hazards due to user error. Anticipating these hazards and developing strategies to mitigate the risk they present is the objective of hazard analysis (Higson, 2002). Mojdehbakhsh et al. (1994) describe another approach which they call retrofitting safety. It is a lifecycle approach for software-controlled medical device systems, which integrates process with traceability. The purpose of retrofitting is demonstrating that existing and ongoing products are safe and conform to current standards that may be stricter than those that were in effect when the product was originally developed. The authors adopt a system-fault tree approach to explicitly identify safety faults and hazards as well as their severity, both in the overall system and in the interfaces between the system and software. In subsequent steps, they develop a process for eliminating safety faults through improved design and final verification of the safety of the revised system. The fault tree approach coupled with a hazard dictionary allows the developers to maintain traceability between the system requirements, hazards and identified faults, critical operations, and mitigation techniques. Thus, this approach integrates a process approach with explicit traceability to create a database to support the safety of the product across its lifecycle.

For consumer products, new approaches for traceability of lifecycle information during production include using knowledge-based tools to understand the complex relationships in product structure. They include: (1) capturing information across the product lifecycle based on a holonic definition of the product and its lifecycle (Terzi et al., 2007); (2) using graph modeling for traceability of the flow of raw materials, parts, intermediates and subassemblies, which are transformed into an end product (Jansen-Vullers et al., 2003); (3) using agentbased information management models to manage information about complex products at the component level (Framling et al., 2006); and (4) developing rule-based approaches to automatically generate traceability relations between feature-based object oriented documents (Jirapanthong and Zisman, 2009). For software products, recent laws such as Sarbanes-Oxley Act of 2002 require organizations to implement change management processes with explicit traceability coverage for any parts of a software product that potentially impact the balance sheet. Best practices for implementing effective automated traceability for this purpose have been explored (Cleland-Huang et al., 2007).

As safety becomes a recognized part of product lifecycle management, research will be needed to determine if hazard analysis processes and/or traceability approaches lead to safer products and fewer recalls. In designing a risk prevention strategy, are hazard analyses sufficient or do they need to be integrated with traceability for maximum effectiveness? How do "smart" traceability approaches using artificial intelligence and knowledge-based technologies perform relative to more traditional approaches, and are they cost-effective? How can these approaches be integrated with quality information systems? 


\subsection{Traceability and recalls}

Large global recalls associated with recent product safety events, for example the Chinese melamine-adulterated milk contamination in 2008, the adulterated heparin in 2008 and the Toyota recall of 2011, have made the development of tools and technologies for traceability through the supply chain a critical issue in risk control. For consumer products, traceability studies have addressed access to the supplier network for more immediate recall of products (Dai et al., 2010; Lee and Park, 2008). The ability to trace a food product as it travels through different supply chains is useful for preventing consumers' hazards and ultimately assuring the quality and safety of foodstuffs (Rábade and Alfaro, 2006). However, with respect to medical products, such as pharmaceuticals and medical devices, the ability to track and trace is critical to detecting if a product is counterfeit while also deterring intentional contamination, adulteration and diversion of legal products. This is an area where technology originally developed for tracking inventory and assets in the supply chain has proven to be very useful.

Synergistic with the ability to track and trace is the development of an electronic pedigree which can provide information about the route of a product at the package level through the supply chain from manufacture to final use. Due to the special challenges in ensuring the safety of the pharmaceutical supply chain, recent legislation is requiring that all pharmaceuticals sold have an electronic pedigree or some unique product identification (Grackin, 2008; Lawson, 2009). Congress has recently granted the FDA the authority to establish a unique device identifier (UDI) system for medical devices. While not yet developed, the UDI would identify the device through the supply chain and include other identifying information (Department of HHS FDA, 2009). In addition, to providing authentication of the product, these identifiers would provide critical information in the event of a recall. The ultimate goal is to have complete transparency of documents, information, and goods across borders. While many equate the use of the ePedigree with an RFID tag, Lawson (2009) points out that it can be used with other optical technologies such as two dimensional bar coding and optical character readers. RFIDs are already considered a supply chain technology, but many consider them an inventory tracking tool that is used to address inaccurate inventory records. The use of RFID for tracking and tracing is still in its infancy, but it has great potential as the price of the tags declines and more companies adopt the technology (Alfaro and Rábade, 2009; Kumar and Putnam, 2008; Lee and Özer, 2007; Schmidt, 2008; Tang, 2008).

Traceability systems can bring additional benefits. For instance, Wang et al. (2010) have developed an optimization model that uses traceability data in combination with operations factors to develop an optimal production plan. Similarly, Rábade and Alfaro (2006) and Alfaro and Rábade (2009), who investigated the implementation of traceability systems in Spanish food supply chains, claim that companies involved in their studies recovered their investment in less than 2 years and had significant improvements in supply, warehousing, inventory management and production. Additional research is needed to establish the value of RFIDs in 
traceability systems across industries. While they have a number of possible uses, do ePedigrees and supply chain technologies actually reduce losses due to counterfeiting? Further research might evaluate how effectively these systems can help to identify products which may have been exposed to contamination or adulteration. Can they help in the event of a recall by quickly identifying which items are actually at risk? Tang (2008) suggests that further safety problems can occur when recalled products are sold on auction websites such as Ebay or aftermarket channels instead of being disposed. Can these technologies help improve the customer return rate and assure that recalled products aren't resold?

Finally, in the area of recall management, there are several unresolved questions related to risk discovery. They include identifying a product safety problem, mitigating the risk from a recall, and learning from a recall. One of the critical issues in identifying safety problems is the sharing of timely and accurate reporting of information regarding product reliability and malfunctions. Maisel (2005) states there are no uniform standards for reporting and managing advisories for Class III medical devices like pacemakers and ICDs. He argues that there is a need for better reporting of confirmed cases of device malfunctions, and further, that manufacturers should be required to publish detailed data on the reliability of their devices on an annual basis. Yet he cautions that the observed failure rate will always be an underestimate of the true failure rate because of underreporting and patient deaths that may have been attributed to another cause.

Echoing this same argument, Tang (2008) states that many companies lack the type of timely and complete information required to confidently make the decision to recall. However, he notes that a delay in issuing a recall can lead to higher losses and risks more damage to the firm's reputation. Research is needed to determine how information sharing coupled with "smart" IT solutions like data-mining techniques or pattern recognition methods can help in detecting a safety problem and its likely root cause for purposes of making a timely recall decision. However, companies may be wary of sharing information that they view as proprietary and possibly damaging. The bottleneck may lie in having enough data and information to use these sophisticated information technologies in managing recalls. Operations management research that addresses information sharing in collaborative supplier relationships may provide insights to how product safety information can be collaboratively shared within an industry.

A second question is how to best mitigate the risks and losses associated with a recall. Communication is a key element of an effective recall process (Dani and Deep, 2010). These authors claim that speed of response is the most crucial variable to control the effects of risk. This is also supported by Roth et al. (2008) who identify two relevant time constructs: the time between discovery and reporting, and the time for recovery from disruptions. Furthermore, Ren's (2000) study on behavior in crisis situations indicates that their impact can be reduced 
significantly if the response is prompt. Effective response involves the detection of a crisis, the scoping of the problem, the identification of affected areas and the execution of the recall management process (Kumar and Budin, 2006).

A third question relates to learning from recalls. This question is motivated by the work of Thirumalai and Sinha (2011) who used an event study to demonstrate that the financial impact of a recall, in terms of capital market impact, was insignificant in the medical device industry, in contrast to studies in other industries that suggest strong financial penalties associated with a recall. They observed a learning effect with recalls whereby the likelihood of a recall decreased with the cumulative recall experience of a firm. However, the actual learning mechanism is a topic for further research. The authors hypothesized that the firm could learn from its own experiences and reduce the number of recalls over time by improving its product designs, manufacturing processes, and even its risk management strategies. Another possibility is vicarious learning. Since the medical device industry has a high number of recalls, established firms in the industry have not only learned from their own experiences, but they may learn from the experiences of others in the industry. Thus, how an organization learns in the face of product safety problems and recalls is an open research question.

\subsection{Supplier relationships}

The final area that offers challenges for further research is the management of supply chain relationships (Rábade and Alfaro, 2006; Alfaro and Rábade, 2009; Dani and Deep, 2010). As companies have outsourced manufacturing to lower cost countries around the world, there has been concern that pressures for lower costs, combined with the additional complexity of the supply chain, will continue to lead to safety problems. An important issue is the relative benefits of vertical integration versus outsourcing with respect to safety. Recent work by Novak and Stern (2008) looks at the impact of vertical integration on the dynamics of performance over the automotive product development lifecycle. One risk prevention strategy would involve factoring product safety issues into the supplier selection decision. Grackin (2008) argues that using a total sourcing model, rather than the traditional cost-based models, may make sense for product safety. She argues that a more comprehensive sourcing model would also consider the costs of risk management should the product be contaminated or adulterated. The high costs associated with supply disruption, product liability and potential recall might indicate that some low-cost suppliers are really high-cost suppliers when the expected costs of safety risk are considered. Voss et al. (2009) also identify the role of supplier selection in food safety as another potential area for research. In the automotive industry, Park et al. (2011) explore whether quality management practices are different among suppliers whose performance has been rated high, medium or low and which practices contribute to the differences. 
A second question is how to coordinate and monitor the behavior of suppliers with respect to product safety. Tang (2008) points out that in the case of the Mattel toy recall, the company had developed a certification program and rigorous testing rules to make sure that its Chinese contractors adhered to standards for the allowable levels of lead in paint. Yet some subcontractors were careless, while others intentionally violated the rules. While no risk control system is perfect, research has focused on developing adequate control mechanisms within an organizational to manage overseas suppliers and the adoption of effective supply chain practices (Teagarden, 2009). Information technologies are increasingly being explored as tools for better coordination and monitoring of the manufacturing process to avoid quality and safety problems (Madhusudan, 2005). These technologies can provide real-time monitoring of processes across a global supply chain that allows companies to manage supplier behavior, especially suppliers located across the globe (Aron et al., 2008).

Companies must invest time and effort in developing not only standards and principles of safety for their suppliers, but must also invest in education and training to build the skills and abilities within the supplier network to assure product safety. A third question is how to effectively educate suppliers. Jiang (2009) showed in a study of noncompliant behavior among Chinese apparel and textile suppliers that the buyer's governance mechanism impacts supplier compliance with Supplier Codes of Conduct. When buyers used more cooperation and collaboration in the relationship, as opposed to threat and coercion, the result was more sustainable compliance. Even the FDA is taking a more collaborative approach and stressing education and training in its practices with foreign countries. Included in FDA's budgets for fiscal year 2010 were specific items designed to improve product quality and safety in the medical device industry. For example, it proposed to provide onsite training to foreign regulators on medical device safety and quality. Also, it proposed to develop computerized training classes on safety and quality standards and to translate them into several languages (Department of HHS FDA, 2009). Another stream of research addresses how to assure supplier relationships that promote and provide incentives for safety with suppliers, including the implementation of cost-sharing contracts for recalls (Chao et al., 2009). In summary, the topic of the role and nature of supplier relationships in a product safety risk strategy is in need of additional research. The current literature indicates that research addressing strategies for risk prevention, risk mitigation and risk control will complement existing work in the area of procurement and supply management.

\section{Conclusions}

This article highlights the many timely and important problems arising in the area of product safety and security that can benefit from an operations management perspective. Although there is a growing literature in the interfaces among and between risk management, quality management and supply chain management, there has been relatively little scholarly work that has addressed the product safety and security challenges that arise in these interfaces. 
Our review identifies primary safety challenges that arise in five highly regulated industries: food, pharmaceuticals, medical devices, consumer products and automotive. With regard to similarities, we note that each of these industries is rapidly globalizing. For each, the supply chain is becoming longer and more complex. Further, while the outsourcing of manufacturing capacity to low-cost countries is on the rise, increasingly design capacity is being outsourced as well. A major conclusion is that in each of these industries, a pressing safety or security problem can be traced back to conditions in the global supply chain. Thus, in the food industry a major problem is contamination, while in pharmaceuticals, it is counterfeiting. The medical device industry is coping with ensuring safety given the rapid pace of technological change. Designing products for safety is the major problem in the consumer products and automotive industries.

In our review we identify four key areas for operations management research in addressing safety and security problems: regulation and standards, product lifecycle management; traceability and recalls, and supplier management. In each area, we demonstrate how existing theories and methodologies of operations management can be used to develop better techniques and solutions for understanding the role supply chain and operations management can play in addressing the product safety and security problems faced by each industry. We hope that the topic of product safety and security will continue to be recognized as timely and relevant to both researchers and practitioners in the area of supply chain management.

\section{Acknowledgements}

The team of guest editors wishes to thank Ken Boyer and Morgan Swink, the Editors-in-Chief for this journal, for their support and encouragement.

\section{References}

Akkerman, R., Farahani, P., Grunow, M., 2010. Quality, safety and sustainability in food distribution: a review of quantitative operations management approaches and challenges. OR Spectrum 32, 863-904.

Alfaro, J.A., Rábade, L.A., 2009. Traceability as a strategic tool to improve inventory management: a case study in the food industry. International Journal of Production Economics $118,104-110$.

Alston, K., 2008. Cradle to cradle design initiatives: lessons and opportunities for prevention through design (PtD). Journal of Safety Science 39, 135-136.

Anderson, S.W., Daley, J.D., Johnson, M.F., 1999. Why firms seek ISO 9000 certification: regulatory compliance or competitive advantage. Production and Operations Management 8 , 28-43.

Aron, R., Bandyopadhyay, S., Jayanty, S., Pathak, P., 2008. Monitoring process quality in off- 
shore outsourcing: a model and findings from multi-country survey. Journal of Operations Management 26, 303-321.

Aruoma, O.I., 2006. The impact of food regulation on the food supply chain. Nutraceuticals and Functional Foods Regulations in the United States and Around the World 221, 119-127.

Bapuji, H., Beamish, P., 2007. Toy Recalls: Is China Really the Problem? Asia Pacific Foundation of Canada, Vancouver, Canada, accessed June 9, 2011 http://www.asiapacific.ca/analysis/pubs/pdfs/commentary/cac45.pdf.

Bapuji, H., Beamish, P., Laplume, A., 2007. Toy Import and Recall Levels: Is There a Connection? Asia Pacific Foundation of Canada, Vancouver, Canada, accessed June 9, 2011 http://www.asiapacific.ca/analysis/pubs/pdfs/rr/2007/toyrecalls.pdf.

Baram, M., 2007. Liability and its influence in designing for product and process safety. Safety Science $45,11-30$.

Barr, P., 2011. U.S. companies losing ground. Modern Healthcare 41, 30.

Bates, H., Holweg, M., Lewis, M., Oliver, N., 2007. Motor vehicle recalls: trends, patterns and emerging issues. Omega 35, 202-210.

Blaise, J.C., Lhoste, P., Ciccotelli, J., 2003. Formalisation of normative knowledge for safe design. Safety Science 41, 241-261.

Blum, J., 2008. China and U.S. clash over cause of heparin deaths. Bloomberg.com. April 21, 2008. http://www.bloomberg.com/apps/news?pid=newsarchive\&sid= aUAE9VN4.xX0\&refer=home\# accessed May 12, 2011.

Chao, G.H., Iravani, S.M.R., Savaskan, R.C., 2009. Quality improvement incentives and product recall cost sharing contracts. Management Science 55, 1122-1138.

Chatterji, A.K., 2009. Spawned with a silver spoon? Entrepreneurial performance and innovation in the medical device industry. Strategic Management Journal 30, 185-206.

Chiang, W.C., Pennathur, A., Mitai, A., 2001. Designing and manufacturing consumer products for functionality: a literature review of current function definitions and design support tools. Integrated Manufacturing Systems 12, 430-448.

Chopra, S., Sodhi, M.S., 2004. Managing risk to avoid supply chain breakdown. Sloan Management Review 46, 53-62.

Cleland-Huang,J., Settimi, R., Romanova, E., Berenbach, B., Clark, S., 2007. Best practices for automated traceability. Computer 40, 27-35. 
Colchester, A.C., Colchester, N.T., 2005. The origin of bovine spongiform encephalopathy: the human prion disease hypothesis. The Lancet 366, 856-861.

Corbett, C.J., Montes-Sancho, M.J., Kirsch, D.A., 2005. The financial impact of ISO 9000 certification in the United States: an empirical analysis. Management Science 51, 1046-1059.

Creaser, W., 2008. Prevention through design (PtD): safe design from an Australian perspective. Journal of Safety Research 39, 131-134.

Creedle, E., 2007. Bon appetit: food recalls and illness reinforce a need for better risk management. Risk Management 54, 40-44.

Curfman, G.D., Morrissey, S., Drazen, J.M., 2009. The medical device safety act of 2009. The New England Journal of Medicine 360, 1550-1551.

Dai, H., Tseng, M.M., Zipkin, P., 2010. Design of traceability systems for product recall. Available at SSRN: http://ssrn.com/abstract $=1619172$.

Dani, S., Deep, A., 2010. Fragile food supply chains: reacting to risks. International Journal of Logistics: Research \& Applications 13, 395-410.

De la Garza, C., Fadier, E., 2005. Towards proactive safety in design: a comparison of safety integration approaches in two design processes. International Journal of Cognition Technology and Work 7, 51-62.

Department of Health and Human Service Food and Drug Administration, 2009. Report on FDA's approach to medical product supply chain safety. July 2009. http://www.fda.gov/downloads/Safety/SafetyofSpecificProducts/UCM184049.pdf accessed May 5, 2011.

Dornbusch, H.D., 1997. Prost!: The Story of German Beer. Siris Books, Boulder, CO. Dowlatshahi, S., 2000. Material selection and product safety: theory versus practice. Omega $28,467-480$.

Drogout, F., Kinnersly, S., Roelen, A., Kirwan, B., 2007. Safety in design - can one industry learn from another. Safety Science 45, 129-153.

EFSA, 2008. EFSA responds to Commission's urgent request on dioxins in Irish pork. Press Release, 10 December 2008, Available at: http://www.efsa.europa.eu/en/press/news/ contam081210.htm accessed May 6, 2011.

ERG, 2006. Good Manufacturing Practices (GMPs) for the 21st Century - Food Processing. Prepared by the Eastern Research Group for the U.S. Food and Drug Administration. Available at: $\quad$ http://www.fda.gov/food/guidancecomplianceregulatoryinformation/currentgood manufacturingpracticescgmps/ucm110877.htm accessed May 24, 2011. 
Fadier, E., Ciccotelli, J., 1999. How to integrate safety in design: methods and models. Journal of Human Factors and Ergonomics in Manufacturing 9, 367-380.

Fadier, E., De la Garza, C., 2006. Safety design: towards a new philosophy. Safety Science 44, 55-73.

Fadier, E., De La Garza, C., Didelot, A., 2003. Safe design and human activity: construction of a theoretical framework from an analysis of a printing sector. Safety Science 41, 759-789.

Flaherty, E., 2008. Safety first: the consumer product safety improvement act of 2008. Loyola Consumer Law Review 21, 372-384.

Framling, K., Ala-Risu, T., Kärkkäinen, M., Holmström, J., 2006. Agent-based model for managing composite product information. Computers in Industry 57, 72-81.

Gallup, A.M., 2008. The Gallup Poll Cumulative Index: Public Opinion, 1998-2007. Rowman and Littlefield, Lantham, Maryland.

Gambatese, J.A., 2008. Research issues in prevention through design. Journal of Safety Research 39, 153-156.

Grackin, A., 2008. Counterfeiting and piracy of pharmaceuticals. IEEE Engineering in Medicine and Biology Magazine 27 (6), 66-69.

HACCPEuropa, 2011. Quality Systems Manual - Product Recall Management. HACCPEuropa, http://www.haccpeuropa.com/Documentation/Manuals/QSM Product Recall Management.pdf accessed May 24, 2011.

Hale, A., Kirwan, B., Kjellen, U., 2007. Safe by design: where are we now? Safety Science 45, 305-327.

Harl, N.E., 2002. US agriculture, food production is threatened by bioterrorism attacks. Ag Lender 6 (4), 10-11.

Hasan, R., Bernard, A., Ciccotelli, J., Martin, P., 2003. Integrating safety into the design process: elements and concepts relative to the working situation. Safety Science 41, 155-179.

Health Industry Group Purchasing Association, 2004. Integrity of the pharmaceutical supply chain: product sourcing for patient safety. American Journal of Health-System Pharmacy 61 , 1889-1894.

Hendricks, K.B., Singhal, V.R., 2003. The effect of supply chain glitches on shareholder wealth. Journal of Operations Management 21, 501-522.

Hendricks, K.B., Singhal, V.R., 2005. Association between supply chain glitches and operating 
performance. Management Science 51, 695-711.

Henson, S., Reardon, T., 2005. Private agri-food standards: implications for food policy and the agri-food system. Private Agri-food Standards: Implications for Food Policy and Agri-food Systems 30, 241-253.

Higson, G.R., 2002. Medical Device Safety: The Regulation of Medical Devices for Public Health and Safety. Institute of Physics Publishing, Philadelphia, PA.

Hornibrook, S.A., McCarthy, M., Fearne, A., 2005. Consumers' perception of risk: the case of beef purchases in Irish supermarkets. International Journal of Retail \& Distribution Management 33, 701-715.

Hora, M., Bapuji, H., Roth, A., 2011. Safety hazard and time to recall: the role of recall strategy, product defect type, and supply chain player in the U.S. toy industry. Journal of Operations Management, doi:10.1016/j.jom.2011.06.006, this issue.

Jackson, G., 2009. Faking it: the dangers of counterfeit medicine on the internet. International Journal of Clinical Practice 63, 181.

Jansen-Vullers, M.H., van Dorp, C.A., Beulens, A.J.M., 2003. Managing traceability information in manufacture. International Journal of Information Management 3, 395-413.

Jiang, B., 2009. The effects of interorganizational governance on supplier's compliance with SCC: an empirical examination of compliant and non-compliant suppliers. Journal of Operations Management 27, 267-280.

Jirapanthong, W., Zisman, A., 2009. XTraQue: traceability for product line systems. Software and System Modeling 8, 117-144.

Johnson, L., 1982. Cost-benefit analysis and voluntary safety standards for consumer products. http://www.rand.org/pubs/reports/2006/R2882.pdf accessed on June 4, 2011.

Karana, E., Hekkert, P., Kandachar, P., 2008. Material considerations in product design: a survey of material aspects used by product designers. Materials and Design 29, 1081-1089.

Karsak, E.E, 2004. Fuzzy multiple objective programming framework to prioritize design requirements in quality function deployment. Computers and Industrial Engineering 47, 149163.

Kinnersley, S., Roelen, A., 2007. The contribution of design to accidents. Safety Science 45, 31-60.

Kirwan, B., 2007. Safety informing design. Safety Science 45, 155-197. 
Kjellen, U., 2002. Transfer of experiences from the users to design to improve safety in offshore oil and gas production. In: Wilpert, B., Fahlbruch, B. (Eds.), System Safety Challenges and Pitfalls of Intervention. Pergamon Press, Oxford.

Kleindorfer, P.R., Saad, G.H., 2005. Managing disruption risks in supply chains. Production and Operations Management 14, 53-68.

Kumar, S., Budin, E.M., 2006. Prevention and management of product recalls in the processed food industry: a case study based on an exporter's perspective. Technovation 26, 739-750.

Kumar, S., Putnam, V., 2008. Cradle to cradle: reverse logistics strategies and opportunities across three industry sectors. International Journal of Production Economics 115, 305-315.

Kumar, S., Schmitz, S., 2011. Managing recalls in a consumer product supply chain - root cause analysis and measures to mitigate risk. International Journal of Production Research 49, 235-253.

Lancaster, I., 2010. Holograms tackle counterfeiting. European Medical Device Technology, 1 (5), 41-42.

Lawson, M., 2009. Helping secure the global pharmaceutical manufacturing supply chain. Drug Discovery Today 14, 533-534.

Layton, L., Miroff, N., 2009. The rise and fall of a peanut empire. The Washington Post. February 14, 2009. http://www.washingtonpost.com/wpdyn/content/article/2009/02/14/ AR2009021401758.html. accessed May 6, 2011.

Lee, D., Park, J., 2008. RFID-based traceability in the supply chain. Industrial Management \& Data Systems 108, 713-725.

Lee, H., Özer, Ö., 2007. Unlocking the value of RFID. Production and Operations Management $16,40-64$.

Lee, H.L., Whang, S., 2005. Higher supply chain security with lower cost: lessons from total quality management. International Journal of Production Economics 96, 289-300.

Lee, M.A., Flynn, B.B., Frohlich, M.T., 2008. All supply chains don't flow through: understanding supply chain issues in product recalls. Management and Organization Review 4, 167-182.

Lewis, M.A., 2003. Cause, consequence and control: towards a theoretical and practical model of operational risk. Journal of Operations Management 21, 205-224.

Liu, J., 2004. Outsourcing to China. Medical Device Technology 15, 15-16. 
Luning, P.A., Devlieghere, F., Verhe, R., 2006. Safety in the Agri-Food Chain. Wageningen Academic Publishers, Wageningen.

Madhusudan, T., 2005. An agent-based approach for coordinating product design workflows. Computers in Industry 56, 235-259.

Magat, W.A., Viscusi, W.K., 1992. Informational Approaches to Regulation. MIT Press, Cambridge, MA.

Magat, W.A., Moore, M.J., 1996. Consumer product safety regulation in the United States and the United Kingdom: the case of bicycles. Rand Journal of Economics 27, 148-164.

Maisel, W.H., 2005. Safety issues involving medical devices: implications of recent implantable carioverter-defibrillator malfunctions. Journal of the American Medical Association 294, 955958.

Manuele, F.A., 2008. Prevention through design (PtD): history and future. Journal of Safety Research 39, 127-130.

Marucheck, A.S., 1987. On product liability and quality control. IIE Transactions 19, 355-360.

Maskus, K.E., Otsuki, T., Wilson, J.S., 2005. The Cost of Compliance with Product Standards for Firms in Developing Countries: An Econometric Study. World Bank Policy Research Working Paper No. 3590. http://ssrn.com/abstract=744664 accessed June 4, 2011.

McKinney, M., 2011. In the hot seat: study questions FDA's fast-track process. Modern Healthcare 41, 16.

Mead, P.S., Slutsker, L., Dietz, V., McCaig, L.F., Bresee, J.S., Shapiro, C., Griffin, P.M., Tauxe, R.V., 1999. Food-related illness and death in the United States. Emerging Infectious Diseases $5,607-625$.

Minhyung, K., 2010. Risks of Global Production Systems: Lessons from Toyota's Mass Recalls. SERI Quarterly, http://www.faqs.org/periodicals/ 201007/2089147441.html, last accessed June 16, 2011.

Mojdehbakhsh, R., Tsai, W.T., Kirani, S., Elliott, L., 1994. Retrofitting software safety in an implantable medical device. IEEE Software 11, 41-50.

Moss, M., 2009. The burger that shattered her life. The New York Times. October 3, 2009. http://www.nytimes.com/2009/10/04/health/04meat.html, accessed May 26, 2011.

Nagurney, A., Yu, M., Qiang, Q., 2011. Supply chain design for critical needs with outsourcing. Papers in Regional Science 90, 123-142. 
Narasimhan, R., Talluri, S., 2009. Perspectives on risk management in supply chains. Journal of Operations Management 27, 114-118.

Novak, S., Stern, S., 2008. How does outsourcing affect performance dynamics? Evidence from the automobile industry. Management Science 54, 1963- 1979.

Panescu, D., 2006. Medical device industry in Wiley Encyclopedia of Biomedical Engineering. Published online on April 14, 2006.

Park, S., Hartley, J., Wilson, D., 2011. Quality management practices and their relationship to buyer's supplier ratings: a study in the Korean automotive industry. Journal of Operations Management 19, 695-712.

Pyke, D., Tang, C.S., 2010. How to mitigate product safety risks proactively? Process, challenges and opportunities. International Journal of Logistics Research and Applications: A Leading Journal of Supply Chain Management 13, 243-256.

Rábade, L.A., Alfaro,J.A., 2006. Buyer-supplier relationship's influence on traceability implementation in the vegetable industry. Journal of Purchasing and Supply Management 12, 39-50.

Ramsey, J., 1985. Ergonomic factors in task analysis for consumer product safety. Journal of Occupational Accidents 7, 113-123.

Ren, C.H., 2000. Understanding and managing the dynamics of linked crisis events. Disaster Prevention and Management 9 (1), 12-17.

Rhea, S., 2007. This problem made in China. Modern Healthcare 37, 29-32.

Rogers, L.K., 2009. Wood pallets cited as cause for McNeil's Tylenol recall. Modern Materials Handling 65, 9-11.

Roth, A., Tsay, A., Pullman, M., Gray, J., 2008. Unraveling the food supply chain: strategic insights from China and the 2007 recalls. Journal of Supply Chain Management 44, 22-39.

Sagot, J.-C., Gouin, V., Gomes, S., 2003. Ergonomics in product design: safety factor. Safety Science $41,137-154$.

Sanchanta, M., Takahasi, Y., 2010. Toyota's recall may top $\$ 5$ billion. Wall Street Journal Eastern Edition 255 (56), B2.

Sarathy, R., 2006. Security and the global supply chain. Transportation Journal 45 (4), 28-51.

Schmidt, C.W., 2008. Face to face with toy safety: understanding an unexpected threat. Environmental Health Perspective 116, A70-A76. 
Schulte, P.A., Rinehart, R., Okun, A., Geraci, C.L., Heidel, D.S., 2008. National prevention through design (PtD) initiative. Journal of Safety Research 39, 115-121.

Sheeran, G., 1992. Bradford Poisoning of 1858. Ryburn Publishing.

Singer, N., 2010. Johnson \& Johnson recalls hip implants. The New York Times. Augues 27, 2010. http://www.nytimes.com/2010/08/27/business/27hip.html accessed June 14, 2011.

Spencer, R., 2009. Two sentenced to death over China melamine milk scandal. The Telegraph. January 22, 2009. http://www.telegraph.co.uk/news/worldnews/ asia/china/4315627/Twosentenced-to-death-overChina-melamine-milk-scandal.html, accessed May 8, 2011.

Sperber, W.H., Stier, R.F., 2009. Happy 50th birthday to HACCP: retrospective and prospective. Food Safety Magazine 42, 44-46.

Sroufe, R., Curkovic, S., 2008. An examination of ISO 9000:2000 and supply chain quality assurance. Journal of Operations Management 26, 503-520.

Tang, C.S., 2006. Perspectives in supply chain risk management. International Journal of Production Economics 103, 451-488.

Tang, C.S., 2008. Making products safe: process and challenges. International Commerce Review 8, 48-55.

Teagarden, M., 2009. Learning from toys: reflections on the 2007 recall crisis. Thunderbird International Business Review 51, 5-15.

Terzi, S., Panetto, H., Morel, G., Garetti, M., 2007. A holonic metamodel for product traceability in product lifecycle management. International Journal of Product Lifecycle Management 2, 253-289.

Terziovski, M., Samson, D., Dow, D., 1997. The business value of quality management systems certification: evidence from Australia and New Zealand. Journal of Operations Management 15, 1-18.

Thirumalai, S., Sinha, K.K., 2011. Product recalls in the medical device industry: an empirical exploration of the sources and financial consequences. Management Science 57, 376-392.

Thomsen, M.R., McKenzie, A.M., 2001. Market incentives for safe foods: an examination of shareholder losses from meat and poultry recalls. American Journal of Agricultural Economics $83,526-538$.

Trienekens, J., Zuurbier, P., 2008. Quality and safety standards in the food industry, developments and challenges. International Journal of Production Economics 113, 107-122. 
Voss, M.D., Closs, D.J., Calantone, R.J., Helferich, O.K., Speier, C., 2009. The role of security in the food supplier selection decision. Journal of Business Logistics 30, 127-155.

Wagner, S.M., Bode, C., 2006. An empirical investigation into supply chain vulnerability. Journal of Purchasing \& Supply Management 12, 301-312.

Wang, X., Li, D., O'Brien, C., Li, Y., 2010. A production planning model to reduce risk and improve operations management. International Journal of Production Economics 124, 463474.

Wein, L.M., Liu, Y., 2005. Analyzing a bioterror attack on the food supply: the case of botulinum toxin in milk. Proceedings of the National Academy of Science of the USA 102, 9984-9989.

Whipple, J.M., Voss, M.D., Closs, D.J., 2009. Supply chain security practices in the food industry. International Journal of Physical Distribution \& Logistics Management 39, 574-594.

White, T., Pomponi, R., 2003. Gain a competitive edge by preventing recalls. Quality Progress $36,41-49$.

Yang, C., 2008. Shaping up China's medical device industry. The China Business Review 35 (May-June), 24-28.

Zarges, T., Giles, B., 2008. Prevention through design (PtD). Journal of Safety Research 39, $153-156$.

Zhu, Y., You, J., Alard, R., 2008. Design quality: the crucial factor for production quality improvement in international production networks. In: 4th International Conference on Wireless Communications, Networking and Mobile Computing, 2008, October 12-14, 2008, pp. 1-7, http://ieeexplore.ieee.org/stamp/stamp.jsp?tp=\&arnumber $=4679520$, accessed on June $2,2011$.

Zhu, Y., You, J., Alard, R., Schonsleben, P., 2009. Design quality: a key to improve product quality in international production. Production Planning and Control 20, 168-177. 